\title{
THE ACADIAN FOREST RESEARCH STATION
}

\author{
By J. C. VENESS
}

DREVIOUS to 1930 the natural resources of the prairie provinces and the railway belt in British Columbia were administered by the Dominion government, and because of the large areas of forest controlled by the central government, the Dominion Forest Service was primarily concerned with administration.

During the year 1916 Dr. B. E. Fernow, Dean of the Faculty of Forestry of the University of Toronto, made a visit to some of the Dominion forest reserves in order to gain a knowledge in regard to the conditions thereon. At this time Dr. Fernow stressed the great need of scientific forest research in Canada.

The following year an advisory committee was formed to study and report on the great need for organizing forest research. The following paragraphs are taken from the report of this committee as submitted to the newly formed Dominion Council for Scientific and Industrial Research.

"Ignorance, lack of definite information, opinions rather than knowledge of facts have characterized, and still to a large extent continue to characterize the methods of handling the forest resources of the Dominion to their detriment and loss."

"Such ignorance can of course be removed only by systematic investiga. tion or research."

In the report of the Director of Forestry for the year 1918 is found the following:-

"Forest study and experiment have been of a desultory character and incidental to administrative work. The Council for Scientific and Indus. trial Research of the Dominion government is providing for the establishment of a forest experiment station in Ontario, plans for which are now being made."

The same year the following appears in the Director's report:-

"The Honorary Council for Scientific Research, in laying out the programme of research work that required development in Canada, included forest research as one demanding immediate attention and recommended an appropriation of $\$ 6,000.00$ for making a beginning in such work, and the amount necessary was provided."

The Council asked the Forestry Branch to undertake the work, and it was decided to establish what later became the "Petawawa Forest Experiment Station," located in the vicinity of Petawawa on land placed at the disposal of the Department of the Interior by the Department of Militia and Defence. 
This really marked the beginning of a Dominion government research programme in forestry.

In 1930 the natural resources were turned over to the western provinces at which time the responsibilities and activities of the Dominion Forest Service became primarily concerned with problems of research.

With the development of this work the necessity of selecting definite areas in each of the main forest regions of Canada to be set aside under the control of the Forest Service as forest experimental areas, was recognized. Possession of such definite areas of timber lands affords the opportunity for study of the fundamental biological and silvicultural problems as well as the carrying out of demonstrations of the results of such studies the practical application of which will be made available to lumber operators and the public generally.

Until 1933, so far as forestry experimental areas were concerned, the Forest Service was restricted to one locality, namely the Petawawa Forest Experiment Station. Considerable work had been done in co-operation with pulp and paper companies in Quebec and New Brunswick, as well as private individuals aside from that carried out on the Petawawa area.

During 1933-34 the work of forest research was consolidated by the establishment of additional stations; in Quebec, the Valcartier; in Manitoba, the Duck Mountain Forest Experiment Station; in Alberta, the Kananaskis Station, and in New Brunswick, the Acadian Forest Experiment Station.

The initial development of these stations was greatly expedited through the splendid co-operation extended by the Department of National Defence, whereby many of the primary improvements were installed as projects under the Unemployment Relief scheme.

The foregoing is a short summary of the development of forest research stations in Canada.

The following is a description of the Maritime station summarizing to date the progress attained at this station.

The Acadian Forest Research Station is situated fifteen miles from Fredericton on what is known as the "Old Richibucto Road." The area which comes under the control of the Dominion Forest Service is divided in two parts, 36 square miles set aside for forestry research, on which area the Dominion Forest Service holds absolute control; a further 33 square miles under the control of the Department of National Defence, but on which area the Forest Service is responsible for the conducting of any or all cutting opera. tions as well as the protection from fire. It is also understood that in so far as possible any blocks on this area necessary for forest research will be set aside for such purpose. 
The whole area lies within the New Brunswick carboniferous formation. The land is a rolling plateau with a maximum height of 600 feet above sea level in the northwest to 100 feet in the extreme south of the area.

The types most prevalent on the area are balsam-spruce, intolerant hard. wood, black spruce and pine. The age-classes range from 1-100. As would be supposed from the types and age-classes the present forest is of fire origin, most of the area having been burned following logging operations. It is a type of forest representing large areas of eastern Canada and offers great facilities for studying growth.

PURPOSE OF THE STATION

The Acadian Station was organized to carry out investigations not only regarding the forest problems of the Maritime provinces but also to investigate problems in forestry of Dominion wide importance.

Because all age-classes and all types found in the Maritime provinces are not represented on the Station area, it will be necessary to conduct considerable of our investigations off of the area and in co-operation with outside agencies.

PERMANENT IMPROVEMENTS SINCE 1934

At the time the relief camps were disbanded the following work had been completed as regards permanent improvements:-

BuILDINGs:-At the administrative site the following buildings had been completed:--the Administrative Building, Superintendent's Cottage, Pump House, and Electric Plant, and Garage. Under construction were the Bunkhouse, Kitchen and Dininghall, Guestcabin, and Barn. The latter buildings were all completed during the past season, so at present all buildings necessary to the administration of the area are ready for occupancy.

ROADs:- Approximately twenty miles of road had been improved for car traffic.

Telephones:-A complete telephone system a total of 30 miles was constructed for the area.

NURSERY:- On the headquarters site a complete forest nursery of four acres has been prepared. This nursery has a complete modern watering system with a separate water system, for the nursery water is pumped from Burpee Mill Stream to a tank on a fifty foot tower. The sprays in the nursery are fed by gravity from this tank.

Fire GUARDS:-Along the southern boundary about ten miles of fire guard has been cut. This guard is thirty-three feet wide.

Control Lines:- Twenty-two miles of line have been cut as a control within the station area. 
Clzanings:-Approximately 300 acres of cleanings have been made. This work was incidental to the wood cutting operations. In the areas where cutting was allowed, for fuel purposes, only the intolerant hardwoods were cut, thus releasing the more important coniferous species.

Because of the necessity of spending our energies toward the development of the area, and because of lack of personnel to carry out investigative work, there has not been as much accomplished along the lines of investigation as would otherwise have been the case. However, considerable work was done along these lines and in the future the work at the station will be primarily concerned with forest research.

The following is a summary of the investigations inaugurated:-

\section{RESEARCH}

Permanent Sample Plots:-Three series of plots were established to study the control of sucker and sprout growth. Each series included four treatments, stumps six inches, two feet, three feet and on one plot in each series the intolerant hardwoods were girdled at D.B.H. A series of plots was established for the three periods: fall, winter, and summer.

Two demonstration thinning plots were established in a balsam-spruce stand.

Plots were established in co-operation with the Entomological Branch of the Department of Agriculture where white pine was planted under different densities of intolerant hardwoods as a study of control of white pine weevil.

NURSERY:- Forty beds have been established on the nursery. The species planted are white spruce, red spruce, white cedar, red pine, white pine, black walnut, butternut, and yellow birch.

Other species at present in the nursery include stock of Douglas fir, Sitka spruce, Scotch pine, and Norway spruce. These were obtained from the Nova Scotia nursery at Lawrencetown.

It is the intention that this nursery be used for experimental purposes and to that end species not native to the Maritimes will be experimented with in an endeavour to find fast growing coniferous species, that will give shorter rotations than our native species.

Experiments are also being conducted with hybrid poplars in an endeavour to develop a disease resistant, fast growing species satisfactory for pulp and match stock.

Planting:- Since 1934 approximately 200,000 trees have been planted on the area. These include red pine, white pine, and white spruce.

As a demonstration a series of acre plots were planted to red pine, white pine, jack pine, Scotch pine, Norway spruce, and white spruce. 
Future of THE Station:-As before stated, many of the investigations carried out at the station will of necessity be connected with young growth. The area is ideal for this purpose and certainly with the vast areas of such growth in Eastern Canada, such investigations are of great importance. The nursery will fill an important role in these studies. The problems to be investigated include type conversion, growth, stand treatment, demonstration thinnings, drainage, insect control, and disease control. In the nursery studies including nursery practice, biotic studies, and tree development will be investigated.

It will be some years before logging operations can be conducted on a commercial scale so that studies of economics connected with production as well as methods of cutting will have to be undertaken for the time being off the area.

I think it will be conceded that the Acadian Forest Experiment Station is off to a good start and will in the future serve a long felt need to facilitate the carrying out of forest research in the Maritime provinces. 